\title{
Potensi Bakteri Simbion Endofit Mangrove Avicennia marina Sebagai Antifouling
}

\author{
Nor Sa'adah* dan Alifia Rizky Novitasari \\ Departemen Oseanografi, Fakultas Teknik dan Ilmu Kelautan, Universitas Hang Tuah \\ Jl. Arief Rahman Hakim No. 150, Keputih, Sukolilo, Surabaya, Jawa Timur 60111 Indonesia \\ ${ }^{*}$ Corresponding author: saadah1809@gmail.com
}

\begin{abstract}
ABSTRAK: Biofouling merupakan organisme mikro dan makrofouling yang menempel pada substrat terendam. Pencegahan terhadap organisme biofouling disebut antifouling. Antifouling menggunakan campuran cat Tributyltin organotin. Cat antifouling mengandung bahan beracun dan tidak ramah lingkungan. Bakteri simbion memiliki kandungan metabolit sekunder, seperti tanin, steroid dan triterpenoid. Penelitian ini bertujuan untuk memperoleh bakteri antifouling melalui proses isolasi bakteri yang diperoleh dari akar mangrove Avicennia marina dan menganalisis zona hambat bakteri simbion mangrove Avicennia marina sebagai antifouling. Metode yang digunakan diawali dengan isolasi bakteri akar mangrove Avicennia marina, identifikasi bakteri, dan uji aktivitas antifouling. Hasil yang diperoleh dari isolasi bakteri, yaitu 21 bakteri simbion endofit dan sampel akar bagian luar diperoleh 15 bakteri epifit. Uji zona hambat bakteri endofit yang berpotensi sebagai antifouling dari tumbuhan mangrove Avicennia marina yaitu memiliki ukuran zona hambat kategori kuat karena $>10 \mathrm{~mm}$.
\end{abstract}

Kata kunci; Biofouling, Antifouling, Avicennia marina, bakteri simbion

\section{Potential of Avicennia marina Endophytic Symbiont Bacteria as Antifouling}

ABSTRACT: Biofouling is micro-organism and makrofouling attached to the submerged substrate. Prevention of biofouling organism called antifouling.Tributyltin organotin was using to mixture antifouling paint. Antifouling paints containing toxic and environmentally unfriendly. Symbiotic bacteria have secondary metabolites, there are tanin, steroid, and triterpenoid. This research aimed to obtain antifouling bacteria through isolation process of bacteria obtained from the roots of mangrove Avicennia marina, and analyze the bacterial symbiont inhibitory zone of mangrove Avicennia marina as antifouling. The method was beginning with the isolation of bacteria roots of mangrove Avicennia marina, identification of symbiotic bacteria, and the antifouling activity test. Results obtained from the isolation of bacteria, there are 21 symbiotic endophytic on a sample of the inner root, and 15 epiphytic bacteria on a sample of the outer root. Endophytic bacteria inhibition zone test potential as antifouling from mangrove Avicennia marina that was from the root part that inhibitory zone size strong category for $>10 \mathrm{~mm}$.

Keywords: Biofouling, Antifouling, Avicennia marina, bacterial symbionts

\section{PENDAHULUAN}

Pencemaran lingkungan dapat diakibatkan oleh beberapa faktor, salah satunya adalah yang berasal dari bahan kimia, seperti senyawa Tributyltin organotin yang merupakan bahan aditif yang digunakan sebagai cat antifouling. Efek akumulasi Tributyltin organotin yang paling berbahaya adalah kegagalan pada sistem reproduksi biota laut, karena akan mengakibatkan penurunan populasi yang diikuti kepunahan spesies dan berujung pada gangguan ekosistem keseluruhan (Mnsen et al., 2016).

Mangrove dikenal sebagai penghasil senyawa metabolit alami dengan aktivitas biologi, antara lain antibakteri, antiviral atau antivirus, antidiare, antifeedant, insectidal, cytotoxic, dan lain sebagainya. Mangrove Avicennia marina yang berada di India terbukti dapat mencegah perkembangan organisme biofouling (Manilal et al., 2009). 
Biofouling merupakan organisme mikro dan makrofouling yang menempel pada substrat terendam yang berada di ekosistem perairan, seperti pada lambung kapal, dan dermaga (Ramasubburayan et al., 2017). Penumpukan biofouling sering terjadi pada moda transportasi laut yaitu kapal laut, hal ini dapat menyebabkan kecepatan kapal berkurang hingga $40 \%$ sehingga konsumsi bahan bakar meningkat sampai dengan 30\%. Berkurangnya kecepatan kapal mengakibatkan tertundanya waktu berlayar (Syahputra dan Almuqaramah, 2019).

Antifouling adalah pencegahan terhadap organisme biofouling. Antifouling biasanya menggunakan bahan Tributyltin organotin sebagai campuran cat yang digunakan untuk membasmi organisme biofouling (Prabhakaran et al., 2012). Tributyltin organotin terbukti ampuh untuk mencegah biofouling namun tidak ramah bagi lingkungan. Tahun 2008 Tributyltin organotin resmi dilarang oleh International Maritime Organization (Cahyaningtyas et al., 2017).

Bagian dari mangrove yang bisa digunakan sebagai antifouling adalah akar mangrove A.marina, akar sebagai penyerap air dan hara mineral. Menurut Syahputra dan Almuqaramah, (2019) kandungan senyawa tanin yang terdapat pada sampel akar terbukti dapat menghambat biofouling. Bakteri simbion endofit diisolasi dari sampel akar, karena adanya keterlibatan bakteri simbion endofit dengan tumbuhan inangnya dalam proses metabolisme. Sehingga kandungan metabolit sekunder hampir sama dengan inangnya, kandungan metabolit sekunder antara lain tanin, steroid, dan triterpenoid (Marhaeni et al. 2011).

Penelitian mengenai potensi mangrove $A$. marina sebagai antifouling sudah pernah dilakukan sebelumnya menggunakan ekstrak kulit batang mangrove $A$. marina terbukti dapat mencegah perkembangan organisme Patella vulgate (Manilal et al., 2009). Cahyaningtyas et al. (2017) melakukan penelitian dengan organisme uji kerang hijau menggunakan ekstrak daun $A$. marina tidak memberikan pengaruh nyata terhadap pelekatan organisme Perna viridis. Penelitian yang dilakukan oleh Zhang et al. (2018) menggunakan isolasi fungi atau jamur yang diperoleh dari sedimen mangrove menghasilkan 17 jamur yang berpotensi sebagai antifouling. Berdasarkan uraian di atas tujuan penelitian ini adalah menganalisis bakteri yang berpotensi sebagai antifouling dan menganalisis kategori zona hambat bakteri simbion mangrove $A$. marina sebagai antifouling. Bakteri dipilih karena bakteri dapat dikultur, sehingga tidak mengambil secara berlebihan atau mengeksploitasi mangrove $A$. marina.

\section{MATERI DAN METODE}

Penelitian dilaksanakan pada September 2019 hingga Januari 2020 di Kawasan Konservasi Mangrove Pamurbaya, Surabaya dengan 3 stasiun (Tabel. 1). Isolasi bakteri simbion mangrove $A$. marina dan uji aktivitas antifouling dilakukan di Laboratorium Mikrobiologi Universitas Hang Tuah Surabaya.

Alat dan bahan yang digunakan untuk pengambilan sampel, isolasi, purifikasi, dan identifikasi morfologi merupakan alat dan bahan steril. Alat-alat yang terbuat dari kaca sebelum digunakan dicuci dan dikeringkan. Alat-alat tersebut kemudian dibungkus dengan kertas dan disterilisasi menggunakan autoclave pada suhu $121^{\circ} \mathrm{C}$ selama 20 menit kemudian dikeringkan dengan oven (Radjasa et al., 2007).

Pembuatan media zobell menggunakan bahan yeast, peptone, dan agar. Bahan-bahan pembuatan media zobell ditimbang sesuai dengan kebutuhan yang akan digunakan dan dihomogenkan dengan air laut steril kemudian media disterilisasi pada suhu $121^{\circ} \mathrm{C}$ selama 15 menit (Radjasa et al., 2007).

Tabel 1. Lokasi Pengambilan Sampel Mangrove A. marina

\begin{tabular}{|c|c|c|}
\hline Stasiun & Koordinat & Keterangan \\
\hline 1. & $7^{\circ} 18 ' 25.30^{\prime \prime}$ LS - $112^{\circ} 49^{\prime} 16.56 "$ BT & dekat dengan daratan atau jogging track. \\
\hline 2. & 7¹8'29.36" LS - 11249'41.75" BT & $\begin{array}{l}\text { dekat muara sungai atau jogging track muara } \\
\text { sungai. }\end{array}$ \\
\hline 3. & 7¹8'19.80" LS - 11250'40.72" BT & di daerah muara sungai. \\
\hline
\end{tabular}


Pengambilan sampel dilakukan dengan metode purposive sampling yaitu suatu metode pengambilan sampel yang dilakukan dengan mengambil subjek bukan berdasarkan strata, random atau daerah tetapi berdasarkan atas adanya tujuan tertentu (Arikunto, 1993 dalam Pratama et al, 2014). Sampel kulit akar mangrove $A$. marina yang diperoleh kemudian dimasukkan ke dalam plastik ziplock dan diberi label (stasiun, waktu dan tanggal pengambilan). Sampel kemudian ditempatkan pada cool box dan dibawa menuju laboratorium mikrobiologi Universitas Hang Tuah Surabaya.

Sampel kulit akar mangrove dibersihkan dengan cara disemprot air laut steril untuk membersihkan bakteri perairan yang menempel pada permukaan sampel. Isolasi bakteri simbion endofit dilakukan dengan cara mengambil sampel kulit akar bagian dalam, sedangkan isolasi bakteri epifit dilakukan dengan cara mengambil sampel kulit akar bagian luar. Sampel tersebut dipisah bagian luar dan bagian dalam. Selanjutnya, dihaluskan kemudian ditimbang sebanyak $1 \mathrm{gr}$ (Wiguna et al., 2016). Masing-masing sampel dilakukan pengenceran dengan cara memasukkan $1 \mathrm{gr}$ sampel kedalam tabung reaksi berisi $9 \mathrm{~mL}$ air laut steril sehingga diperoleh pengenceran sampel sebesar $10 \mathrm{~mL}$ yang disebut pengenceran $10^{-0}$. Dari pengenceran $10^{-0}$ tersebut diambil $1 \mathrm{~mL}$ sampel dengan pipet steril dan dimasukkan ke dalam tabung reaksi yang berisi $9 \mathrm{~mL}$ air laut steril maka akan diperoleh pengenceran $10^{-1}$. Demikian selanjutnya sehingga diperoleh pengenceran sampel $10^{-2}$, $10^{-3}, 10^{-4}$ dan $10^{-5}$ (Radjasa et al., 2007).

Seri pengenceran $10^{-1}, 10^{-3}$ dan $10^{-5}$ dari sampel kulit akar bagian luar dan sampel kulit akar bagian dalam masing-masing diambil $1 \mathrm{~mL}$ dan disebarkan ke dalam cawan petri steril yang sudah diberi media agar zobell dengan menggunakan spreader (Nandhini dan Ravathi, 2016). Kemudian cawan petri ditutup dan dibungkus dengan plastik wrap untuk menghindari kontaminasi. Cawan petri tersebut selanjutnya diinkubasi pada suhu $27^{\circ} \mathrm{C}-30^{\circ} \mathrm{C}$ selama $3 \times 24$ jam, untuk mendapatkan bakteri simbion endofit dan bakteri epifit. Koloni bakteri yang tumbuh diamati atau diidentifikasi bentuk koloni, warna dan tekstur koloninya dengan acuan buku mikrobiologi umum (Waluyo, 2018).

Purifikasi bakteri dilakukan dengan metode goresan (streak method). Koloni bakteri dipisahkan dengan jarum ose berdasarkan perbedaan warna dan bentuk koloni pada media zobell dalam cawan petri baru. Isolat murni yang diperoleh kemudian disimpan pada media agar miring di tabung reaksi (Radjasa dan Sabdono, 2003).

Uji aktivitas antifouling dilakukan menggunakan metode overlay. Bakteri simbion endofit dilawankan dengan bakteri epifit. Bakteri simbion endofit sebagai antifouling dan bakteri epifit sebagai biofouling. Isolat bakteri endofit mangrove diambil satu ose dan ditanam pada media zobell dicawan petri dan dibentuk menjadi bulatan kecil. Selanjutnya, media zobell soft agar yang telah diberi bakteri epifit dari media cair sebanyak $1 \mathrm{ml}$ dituang di atas media zobell yang berisi bakteri endofit. Cawan petri dibungkus dengan plastik wrap dan diinkubasi pada suhu kamar selama 3×24 jam. Pembentukan zona hambat di sekeliling isolat bakteri menunjukkan isolat bakteri tersebut mempunyai aktifitas antifouling. Zona hambat yang terbentuk diukur menggunakan jangka sorong. dengan ketelitian $0.05 \mathrm{~mm}$ (Pratama et al., 2014).

\section{HASIL DAN PEMBAHASAN}

Isolat bakteri yang diperoleh dalam penelitian ini sebanyak 21 bakteri endofit dan 15 bakteri epifit. Isolat bakteri tersebut diidentifikasi secara morfologi berdasarkan warna, ukuran, bentuk, margin dan elevasi pada masing-masing koloni yang tumbuh di media zobell. Berikut hasil identifikasi secara morfologi koloni bakteri simbion endofit dan epifit pada sampel akar mangrove $A$. marina (Tabel 2 dan Tabel. 3).

Kelimpahan bakteri simbion endofit maupun epifit dapat dipengaruhi oleh faktor lingkungan. Hal ini sesuai pernyataan Yulma et al., (2017) bahwa bertambahnya salinitas memberikan efek negatif terhadap kelimpahan dan keanekaragaman bakteri. Tingginya tingkat salinitas mampu menghambat pertumbuhan koloni bakteri sehingga menyebabkan tingkat aktivitas bakteri sangat rendah dan terjadi shock osmotic atau toksik. Suhu juga dapat berpengaruh terhadap kelimpahan mikroorganisme bakteri yang berada di mangrove, semakin tinggi suhu maka dapat mematikan mikroorganisme bakteri yang berada di mangrove.

Kemampuan bakteri simbion endofit dalam menghambat bakteri epifit diperlihatkan pada zona hambat atau zona bening disekeliling bakteri simbion endofit. Kemampuan bakteri simbion endofit 
dilihat berdasarkan besar zona hambat yang memperlihatkan besarnya potensi bakteri endofit tersebut dalam melakukan penghambatan terhadap bakteri epifit. Hal ini sesuai dengan pernyataan Marhaeni et al., (2011) bahwa, kemampuan yang dimiliki bakteri simbion endofit tersebut kemungkinan karena koevolusi terjadinya transfer genetik dari tumbuhan inangnya ke bakteri simbion endofit.

Tabel 2. Identifikasi morfologi koloni bakteri endofit sampel akar

\begin{tabular}{lllllll}
\hline K. Isolat & No. Bakteri & Warna & Ukuran & Bentuk & Margin & Elevasi \\
\hline AVAD.1.1. & 1 & Kuning & Kecil & Circular & Entire & Flat \\
& 2 & Kuning & Titik & Circular & Entire & Flat \\
& 3 & Putih & Sedang & Irregular & Serrate & Flat \\
AVAD.1.3. & 1 & Kuning & Kecil & Circular & Entire & Flat \\
& 2 & Kuning & Sedang & Irregular & Lobate & Flat \\
AVAD.1.5. & 1 & Putih & Sedang & Irregular & Serrate & Flat \\
& 2 & Putih & Sedang & Irregular & Serrate & Flat \\
& 3 & Kuning & Kecil & Spindle & Serrate & Flat \\
& 4 & Putih & Kecil & Spindle & Serrate & Flat \\
AVAD.2.1. & 1 & Putih & Sedang & Circular & Entire & Flat \\
& 2 & Kuning & Sedang & Circular & Entire & Flat \\
AVAD.2.3. & 1 & Putih & Besar & Irregular & Lobate & Flat \\
& 2 & Kuning & Sedang & Irregular & Serrate & Flat \\
& 3 & Putih & Sedang & Irregular & Serrate & Flat \\
& 4 & Putih & Kecil & Circular & Serrate & Flat \\
AVAD.3.1. & 1 & Putih & Kecil & Irregular & Lobate & Flat \\
AVAD.3.3. & 1 & Putih & Kecil & Spindle & Lobate & Flat \\
& 2 & Putih & Titik & Circular & Entire & Flat \\
AVAD.3.5. & 1 & Transparan & Besar & Irregular & Lobate & Flat \\
& 2 & Kuning & Besar & Irregular & Lobate & Flat \\
& 2 & Putih & Kecil & Irregular & Lobate & Flat \\
\hline
\end{tabular}

Keterangan: $\operatorname{AVAD}(A$. marina akar dalam), angka pertama yaitu stasiun, angka kedua yaitu pengenceran.

Tabel 3. Identifikasi morfologi koloni bakteri epifit sampel akar

\begin{tabular}{|c|c|c|c|c|c|c|}
\hline K. Isolat & No. Bakteri & Warna & Ukuran & Bentuk & Margin & Elevasi \\
\hline \multirow[t]{2}{*}{ AVAL.1.1. } & 1 & Pink & Kecil & Circular & Entire & Flat \\
\hline & 2 & Putih & Kecil & Circular & Entire & Flat \\
\hline \multirow[t]{2}{*}{ AVAL.1.3. } & 1 & Putih & Kecil & Circular & Entire & Flat \\
\hline & 2 & Kuning & Kecil & Irregular & Entire & Raised \\
\hline AVAL.1.5. & 1 & Putih & Sedang & Circular & Entire & Flat \\
\hline \multirow[t]{2}{*}{ AVAL.2.1. } & 1 & Putih & Sedang & Circular & Entire & Flat \\
\hline & 2 & Kuning & Sedang & Circular & Entire & Flat \\
\hline \multirow[t]{2}{*}{ AVAL.2.3. } & 1 & Putih & Kecil & Irregular & Lobate & Flat \\
\hline & 2 & Kuning & Kecil & Irregular & Lobate & Flat \\
\hline AVAL.2.5. & 1 & Kuning & Kecil & Circular & Entire & Flat \\
\hline AVAL.3.1. & 1 & Kuning & Titik & Circular & Entire & Flat \\
\hline \multirow[t]{2}{*}{ AVAL.3.3. } & 1 & Kuning & Sedang & Irregular & Lobate & Flat \\
\hline & 2 & Putih & Kecil & Circular & Entire & Flat \\
\hline \multirow[t]{2}{*}{ AVAL.3.5. } & 1 & Kuning & Sedang & Irregular & Lobate & Flat \\
\hline & 2 & Kuning & Kecil & Circular & Entire & Flat \\
\hline
\end{tabular}


Penelitian ini memperlihatkan zona hambat dari bagian akar memiliki ukuran zona hambat kategori kuat karena $>10 \mathrm{~mm}$. Hal ini sesuai pendapat Kusmawarti et al., (2008) bahwa, ukuran zona hambat dikategorikan lemah jika zona hambatnya $<5 \mathrm{~mm}$, sedang jika berukuran $5-10 \mathrm{~mm}$, kategori kuat $10-20 \mathrm{~mm}$ dan dikategorikan sangat kuat jika zona hambat berukuran $20-30 \mathrm{~mm}$. Kategori zona hambat kuat pada penelitian ini, karena keterlibatan bakteri endofit dalam jaringan inangnya dalam hal metabolisme yang saling menguntungkan. Bakteri endofit memperoleh nutrisi untuk melengkapi siklus hidupnya dari tumbuhan inangnya dan tumbuhan inang memperoleh proteksi atau keuntungan lain dari hasil kerjasama metabolisme (Marhaeni et al, 2011).

Aktivitas antifouling yang ditunjukkan kode isolat AVA.2.1.2. yang dilawankan dengan AVAL.2.3.2. menunjukkan adanya zona hambat dengan diameter $19 \mathrm{~mm}$. Aktivitas antifouling pada kode isolat AVAD.3.3.1 yang dilawankan dengan AVAL.3.3.1 menunjukkan adanya zona hambat dengan diameter $20 \mathrm{~mm}$. Aktivitas antifouling pada kode isolat AVAD.3.3.1. yang dilawankan dengan AVAL.3.5.2 menunjukkan adanya zona hambat dengan diameter $16 \mathrm{~mm}$.

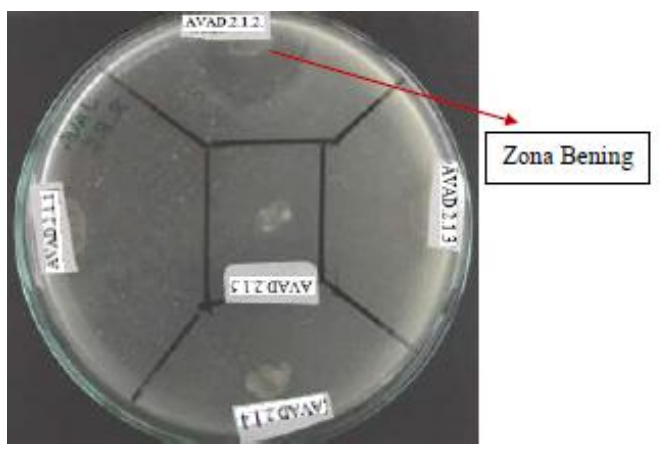

Gambar 1. Uji aktivitas antifouling pada kode isolat AVAD.2.1.2. dilawankan dengan AVAL.2.3.2.

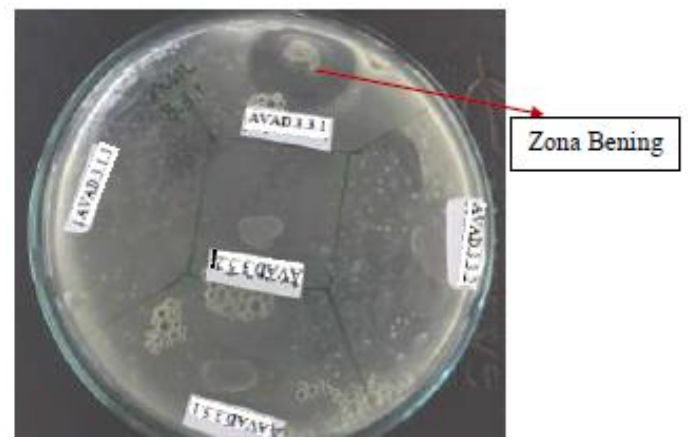

Gambar 2. Uji aktivitas antifouling pada kode isolas AVAD.3.3.1. dilawankan dengan AVAL.3.3.1

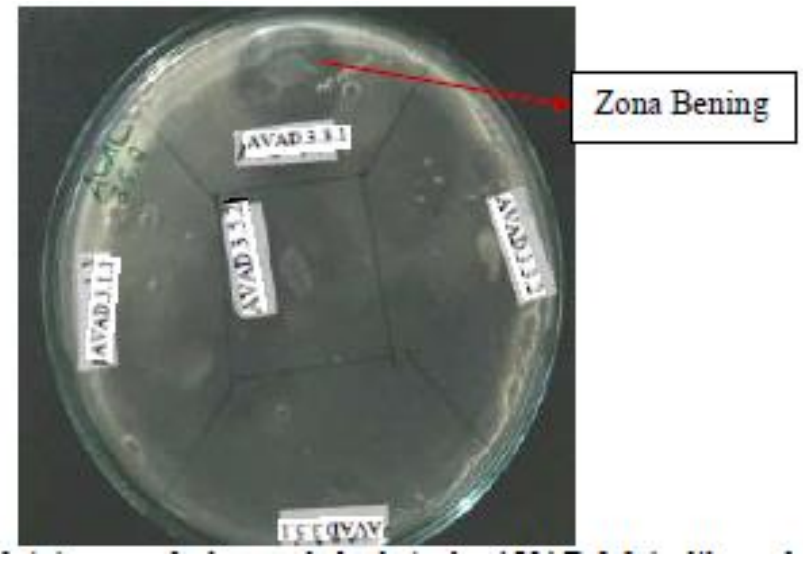

Gambar 3. Uji aktivitas antifouling pada kode isolat AVAD.3.3.1. dilawankan dengan AVAL.3.5.2. 
Aktivitas antifouling pada kode isolat AVAD.3.3.1. yang dilawankan dengan AVAL.3.5.1. menunjukkan adanya zona hambat dengan diameter $18 \mathrm{~mm}$. Aktivitas antifouling pada kode isolat AVAD.3.1.1. yang dilawankan dengan AVAL.3.5.1. menunjukkan adanya zona hambat dengan diameter $18 \mathrm{~mm}$, dan AVAD.3.3.1 yang dilawankan dengan AVAL.3.5.1 menunjukkan adanya zona hambat dengan diameter $18 \mathrm{~mm}$.

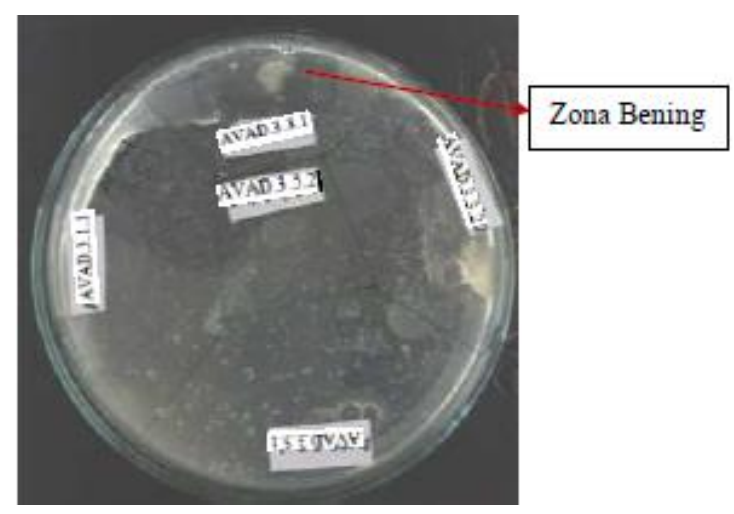

Gambar 4. Uji aktivitas antifouling pada kode isolat AVAD.3.3.1. dilawankan dengan AVAL.3.5.1.

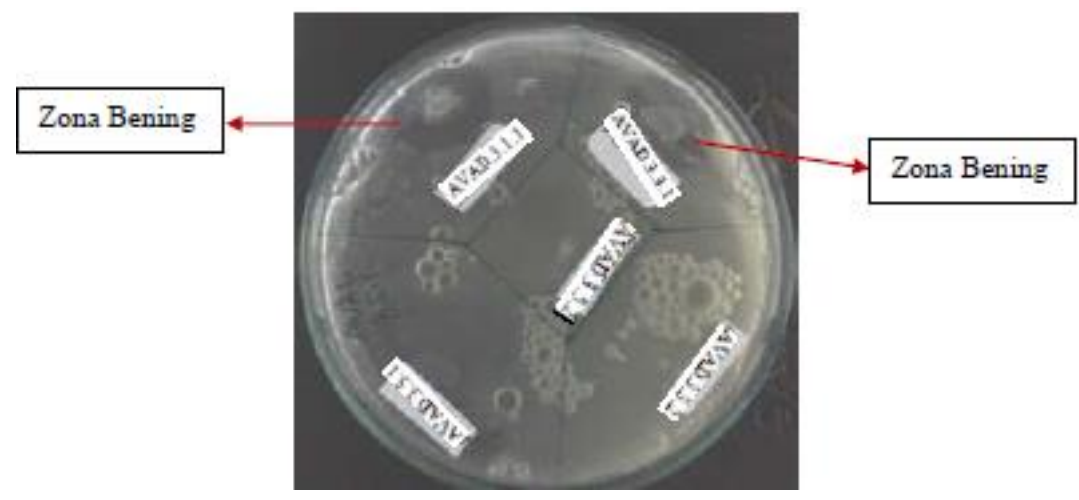

Gambar 5. Uji aktivitas antifouling pada kode isolat AVAD.3.1.1., AVAD.3.3.1 dilawankan dengan AVAL.3.5.1.

Tabel 4. Hasil ukuran zona hambat pada sampel akar yang telah diuji untuk mengetahui aktivitas antifouling

\begin{tabular}{cccc}
\hline No. & $\begin{array}{c}\text { Bakteri Simbion Endofit } \\
\text { (Antifouling Bacteria) }\end{array}$ & $\begin{array}{c}\text { Bakteri Epifit } \\
\text { (Bakteri Uji) }\end{array}$ & Ukuran Zona Hambat $(\mathrm{mm})$ \\
\hline 1. & AVAD.2.1.2. & AVAL.2.3.2. & $18 \pm 0.1$ \\
2. & AVAD.3.1.1. & AVAL.3.3.1. & $20 \pm 0.06$ \\
3. & AVAD.3.1.1. & AVAL.3.5.1. & $18 \pm 0.06$ \\
4. & AVAD.3.3.1. & AVAL.3.5.1. & $18 \pm 0.06$ \\
5. & AVAD.3.1.1. & AVAL.3.5.2. & $16 \pm 0.06$
\end{tabular}

Keterangan: AVAD (Avicennia marina akar dalam), angka pertama yaitu stasiun, angka kedua yaitu pengenceran, dan angka ketiga yaitu bakteri yang diidentifikasi. AVAL (Avicennia marina akar luar), angka pertama yaitu stasiun, angka kedua yaitu pengenceran, dan angka ketiga yaitu bakteri yang diidentifikasi. 
Tabel 5. Parameter lingkungan pengambilan sampel

\begin{tabular}{lllll}
\hline Parameter & Stasiun 1 & Stasiun 2 & Stasiun 3 & \multicolumn{1}{c}{ Referensi } \\
\hline Salinitas & $30 \mathrm{ppt}$ & $29 \mathrm{ppt}$ & $30 \mathrm{ppt}$ & $28-30 \mathrm{ppt}$ (Yulma et al., 2017) \\
Suhu & $31.5^{\circ} \mathrm{C}$ & $31^{\circ} \mathrm{C}$ & $31.4^{\circ} \mathrm{C}$ & $27-31^{\circ} \mathrm{C}$ (Hadiputra dan Damayanti, \\
& & & & $2013)$ \\
$\mathrm{pH}$ & 7 & 6.8 & 7.27 & $6.8-8$ (Sari et al., 2017) \\
\hline
\end{tabular}

Perkembangan zona hambat disekitar bakteri simbion endofit juga dipengaruhi pengambilan sampel pada musim kemarau, karena pada saat musim kemarau terjadi surut terendah di daerah Wonorejo yang menyebabkan mangrove tidak ada masukan air dan mempengaruhi faktor-faktor oseanografi fisika maupun kimia (Tabel. 5), sehingga bakteri yang berada di mangrove tidak begitu melimpah. Hal ini sesuai dengan penelitian Yulma et al., (2017) bahwa bertambahnya salinitas akan memberikan efek negatif terhadap kelimpahan dan keanekaragaman bakteri. Tingginya tingkat salinitas mampu menghambat pertumbuhan koloni bakteri sehingga menyebabkan tingkat aktivitas bakteri sangat rendah akibatnya terjadi shock osmotic atau toksik. Suhu juga dapat berpengaruh terhadap kelimpahan mikroorganisme bakteri yang berada di mangrove, semakin tinggi suhu maka dapat mematikan mikroorganisme bakteri yang berada di mangrove. Hasil penelitian dari Sinatryani et al., (2014) pH juga dapat mempengaruhi kehidupan bakteri, pada umumnya pH tumbuhan tingkat tinggi sesuai dengan mikroba tanah. Aktivitas mikroba tanah akan menurun dengan menurunnya $\mathrm{pH}$ tanah, hal ini yang mempengaruhi kelimpahan bakteri yang berada di mangrove.

Sampel akar terbukti menunjukkan bahwa bakteri simbion endofit ada zona hambat yang dapat menghambat bakteri epifit yang diduga mengandung senyawa metabolit sekunder tanin yang dapat menghambat biofouling. Hal ini sesuai penelitian Syahputra dan Almuqaramah (2019) yang menyatakan bahwa kandungan metabolit sekunder berperan penting dalam menghambat biofouling terutama pada senyawa tanin.

\section{KESIMPULAN}

Hasil dari penelitian menunjukkan adanya bakteri pada sampel akar mangrove $A$. marina berjumlah 21 bakteri simbion endofit dan 15 bakteri epifit. Bakteri simbion endofit yang menunjukkan adanya aktivitas antifouling ditunjukkan dengan adanya zona hambat disekitar bakteri simbion endofit. Analisis zona hambat menunjukkan bahwa bakteri endofit yang berpotensi sebagai antifouling pada bagian akar memiliki ukuran zona hambat kategori kuat yaitu $>10 \mathrm{~mm}$.

\section{DAFTAR PUSTAKA}

Cahyaningtyas, G.A., Feni, I., \& Dewi, C.S.U. 2017. Aktivitas Antifouling Avicennia marina Terhadap Macrofouler Perna viridis. Journal of Fisheries and Marine Science, 1(1):1-5

Hadiputra, M.A., \& Damayanti, A. 2013. Kajian Potensi Makrozoobentos sebagai Bioindikator Pencemaran Logam Berat Tembaga (Cu) di Kawasan Ekosistem Mangrove Wonorejo Pantai Timur Surabaya. Prosiding Seminar Nasional Manajemen Teknologi XVIII, D14-1 - D14-8.

Kusmarwati, Arifah, \& Indriati, N. 2008. Daya Hambat Ekstrak Bahan Aktif Biji Picung (Pangiun edule Reinw) Terhadap Pertumbuhan Bakteri Penghasil Histamin. Jurnal Pascapanen dan Bioteknologi Kelautan dan Perikanan, 3(1):29-35.

Nandhini, S., \& Ravathi, K. 2016. Antifouling Activity of Extracts from Mangroves Against Biofouling Bacteria Isoolated from Boats in Royapuram, Chennai, India. International Journal of Current Microbiology and Applied Sciences, 5(8):324-335.

Manilal, A., Sujith, A., Kiran, G.S., Selvin., J. \& Shakir, C. 2009. Biopotentials of Mangroves Collected from the Southwest Coast of India. Global Journal of Biotechnology and Biochemistry, 4(1):5965. 
Marhaeni, B., Radjasa, O.K., Khoeri, M.M., Sabdono, A., Bengen, D.G., \& Sudoyo, H. 2011. Antifouling Activity of Bacterial Symbionts of Seagrasses against Marine Biofilm-Forming Bacteria. Journal of Environmental Protection, 2(9):1245 - 1249.

Mnsen, F.S., Rumampuk, N., \& Lasut, M. 2016. Deteksi Polutan Tributiltin dalam Jaringan Gastropoda Di Perairan Pelabuhan Manado dan Bitung. Jurnal Pesisir dan Laut Tropis, 1(1):914.

Prabhakaran, S., Rajaram, R., Balasubramanian, V. \& Mathivanan, K. 2012. Antifouling Potential of Extracts from Seaweed, Segrasses and Mangroves Against Primary Biofilm Forming Bacteria. Asian Pasific Journal of Tropical Biomedicine, 2(1): S316-S322.

Pratama, B., Endang, K., Agung, S., Anto, B., \& Susanto, A.B.. 2014. Eksplorasi dan Karakterisasi Bakteri Potensial Penghasil Senyawa Antifouling yang Berasosiasi dengan Alga Coklat (Phaeophyta) di Perairan Kepulauan KarimunJawa Jepara. Jurnal Biologi, 3(3):39-48.

Radjasa, O.K. \& Sabdono, A. 2003. Keanekaragaman Genetik Bakteri Laut Penghasil Senyawa Anti Bakteri dalam Pengendalian Penyakit pada Udang. Laporan Kegiatan Proyek Penelitian IImu Pengetahuan Dasar, Pusat Kajian Pesisir dan Laut Tropis Lembaga Penelitian Universitas Diponegoro.

Radjasa, O.K., Sabdono, A., Junaidi \& Zoochi, E. 2007. Richness of Secondary Metabolite Producing Marine Bacteria Assosiated with Sponge Haliclone sp. Journal of Pharmaca, 3(3): $275-279$.

Ramasubburayan, R., Prakash, S., lyapparaj, P., Sumathi, S., Titus, S., Immanueldan, G. \& Palavesam, A. 2017. Isolation, Screening and Evaluation of Antifouling Activity of Mangrove Associated Bacterium, Bacillus subtilis subsp. subtilis RG. Prociding The National Academy of Science, India, 87(3): 1015-1024.

Sari, S.H.J., Kirana, J.F.A. \& Guntur. 2017. Analisis Kandungan Logam Berat Hg dan Cu Terlarut di Perairan Pesisir Wonorejo, Pantai Timur Surabaya. Jurnal Pendidikan Geografi, 22(1): 1-9.

Sinatryani, D., M.A. Alamsjah., Sudarno., \& Pursetyo, K.T. 2014. Kelimpahan Bakteri Selulolitik Di Muara Sungai Gunung Anyar Surabaya dan Bancaran Bangkalan. Jurnal IImiah Perikanan dan Kelautan, 6(2):143-148.

Syahputra, F., \& Almuqaramah, T.M.H. 2019. Penambahan Ekstrak Larutan Kulit Mangrove pada Cat Minyak Sebagai Antifouling. Aquatic Science Journal, 6(1):37-40.

Waluyo, Lud. 2018. Mikrobiologi Umum. Universitas Muhammadiyah Malang.

Wiguna, A.S., Kusmita, L.\& Radjasa, O.K. 2016. Uji Aktivitas Antibakteri Pigmen Karotenoid dari Isolat Bakteri Simbion Karang Lunak Sarcophyton sp. Terhadap Pertumbuhan Bakteri Staphylococcus aereus ATCC 25923. Jurnal Sains dan Teknologi Farmasi Indonesia, 3(3):92 98.

Yulma, Ihsan, B., Sunarti, Malasari, E., Wahyuni, N., \& Mursyban, M. 2017. Identifikasi Bakteri pada Serasah Daun Mangrove yang Terdekomposisi di Kawasan Konservasi Mangrove dan Bekantan (KKMB) Kota Tarakan. Journal of Tropical Biodiversity and Biotechnology, 2(1):2833.

Zhang, X.Y., Fu, W., Chen, X., Yan, M.T., Huang, X.D., \& J. Bao. 2018. Phylogenetic Analysis and Antifouling Potentials of Culturabel Fungi in Mangrove Sediments from Techeng Isle, China. World Journal of Microbiologi and Biotechnology, 34(90): 1-11. 